\title{
Oxygen radicals, nitric oxide and human inflammatory joint disease
}

\author{
Barry Halliwell
}

Pharmacology Group, King's College, University of London, London SW3 6LX, United Kingdom B Halliwell
Interest in the role of free radicals in rheumatoid arthritis (RA) stems from the seminal work of McCord, ${ }^{1}$ who noted the decreased viscosity of synovial fluid in RA patients and showed that a similar decrease could be produced by exposing synovial fluid, or solutions of hyaluronic acid, to a system generating superoxide radical, $\mathrm{O}_{2}{ }^{\cdot-}$. McCord's observations led to interest in the use of intraarticular injections of the antioxidant enzyme superoxide dismutase as a treatment in RA. However, the clinical data presented did not convince many rheumatologists ${ }^{23}$ and overenthusiastic interpretations of the data may have led to unwarranted scepticism about the real role of free radicals in RA. Let us review our current knowledge.

\section{Basic definitions}

Electrons in atoms and molecules occupy regions of space termed orbitals, each of which holds a maximum of two electrons. A free radical is any species capable of independent existence that contains one or more unpaired electrons-that is, electrons alone in an orbital. Table 1 gives examples.

Radicals react with other molecules in a number of ways. ${ }^{4}$ If two radicals meet, they can combine their unpaired electrons and join to form a covalent bond (a shared pair of electrons). An important example is the fast reaction of $\mathrm{O}_{2}{ }^{--}$with nitric oxide (also a free radical, $\mathrm{NO}^{\circ}$ ) to form the non-radical peroxynitrite: ${ }^{5}$

$$
\mathrm{O}_{2}{ }^{--}+\mathrm{NO}^{\cdot} \rightarrow \mathrm{ONOO}^{-}
$$

A free radical might donate its unpaired electron to another molecule. Thus $\mathrm{O}_{2}{ }^{--}$reduces ferric $\left(\mathrm{Fe}^{3+}\right)$ cytochrome $\mathrm{c}$ to ferrous $\left(\mathrm{Fe}^{2+}\right)$ cytochrome $c$, a reaction often used to assay $\mathrm{O}_{2}{ }^{\cdot-}$ production by activated phagocytes: ${ }^{6}$

$$
\text { cyt c }\left(\mathrm{Fe}^{3+}\right)+\mathrm{O}_{2}{ }^{\cdot-} \rightarrow \text { cyt c }\left(\mathrm{Fe}^{2+}\right)+\mathrm{O}_{2}
$$

A free radical might take an electron from another molecule, thus oxidising it. For example, $\mathrm{O}_{2}{ }^{--}$oxidises ascorbic acid, a process believed to occur in RA: ${ }^{7}$

$$
\begin{aligned}
\text { ascorbate }+\mathrm{O}_{2}^{\cdot-} & +\mathrm{H}^{+} \rightarrow \text { ascorbate radical } \\
& +\mathrm{H}_{2} \mathrm{O}_{2}
\end{aligned}
$$

Left to itself, $\mathrm{O}_{2}{ }^{--}$undergoes the dismutation reaction:

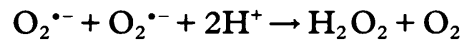

$\mathrm{OH}^{*}$ ) and important non-radical derivatives of oxygen such as $\mathrm{H}_{2} \mathrm{O}_{2}$ and hypochlorous acid (HOCl).

\section{Reactive oxygen species in vivo}

The chemical reactivity of oxygen radicals varies (table 1). The most reactive is hydroxyl radical $\left(\mathrm{OH}^{*}\right)$, which reacts very fast with almost all molecules in vivo. When $\mathrm{OH}^{*}$ is formed, it damages whatever it is generated next to; it cannot migrate within the cell. ${ }^{4}$

NITRIC OXIDE

Whereas $\mathrm{OH}^{\bullet}$ is probably always harmful, other (less reactive) free radicals may be useful in vivo. For example, $\mathrm{NO}^{*}$ is synthesised from L-arginine by many cell types, including chondrocytes. ${ }^{8}$ However, although human phagocytes can make NO, 9 it is not yet clear how often they do so in vivo; much of the work with $\mathrm{NO}^{\circ}$ has investigated rats and mice, both of which species have phagocytes that make $\mathrm{NO}^{*}$ much more readily.

\section{SUPEROXIDE}

Superoxide is produced by phagocytes as a killing mechanism. ${ }^{6}$ Lesser amounts of extracellular $\mathrm{O}_{2}{ }^{-}$may be generated, perhaps as an intercellular signal molecule, by several other cell types, including vascular endothelial cells, osteoclasts, chondrocytes, lymphocytes, and fibroblasts. ${ }^{10-13}$ For example, treatment of human fibroblasts with RA synovial fluid causes $\mathrm{O}_{2}{ }^{--}$secretion. ${ }^{13}$

In addition to this 'deliberate' $\cdot \mathrm{O}_{2}{ }^{- \text {- }}$ generation, some $\mathrm{O}_{2}{ }^{--}$is produced within cells by mitochondria and endoplasmic reticulum, apparently by the unavoidable 'leakage' of electrons onto oxygen from their correct paths in electron transfer chains and by chemical 'autoxidation' reactions. ${ }^{4}$

HYPOCHLOROUS ACID

Another killing mechanism used by neutrophils (but not macrophages) is the enzyme myeloperoxidase, ${ }^{14}$ which uses $\mathrm{H}_{2} \mathrm{O}_{2}$ to oxidise chloride ions into hypochlorous acid ( $\mathrm{HOCl})$, a powerful oxidising and chlorinating agent:

$$
\mathrm{H}_{2} \mathrm{O}_{2}+\mathrm{Cl}^{-} \rightarrow \mathrm{HOCl}+\mathrm{OH}^{-}
$$

Hydrogen peroxide, $\mathrm{H}_{2} \mathrm{O}_{2}$, is not a free radical (no unpaired electrons are present). The global term reactive oxygen species is often used to include the oxygen radicals $\left(\mathrm{O}_{2}{ }^{\cdot-}\right.$ and

\section{Superoxide-nitric oxide interactions} What happens if both $\mathrm{O}_{2}{ }^{--}$and $\mathrm{NO}$ are produced at the same site, for example by 
Table 1 Examples of free radicals

\begin{tabular}{|c|c|c|}
\hline Name & Formula & Comments \\
\hline Hydrogen atom & ${ }^{\star} \mathbf{H}^{\bullet}$ & The simplest free radical known. \\
\hline Trichloromethyl & $\mathrm{CCl}_{3}{ }^{\circ}$ & $\begin{array}{l}\text { A carbon centred radical (the unpaired electron resides } \\
\text { on carbon). } \mathrm{CCl}_{3}{ }^{\circ} \text { is formed during metabolism of } \\
\text { carbon tetrachloride }\left(\mathrm{CCl}_{4}\right) \text { in the liver and } \\
\text { contributes to the toxic effects of this solvent. }\end{array}$ \\
\hline Superoxide & $\mathrm{O}_{2}{ }^{\cdot-}$ & $\begin{array}{l}\text { An oxygen centred radical. Reacts quickly with a few } \\
\text { molecules (such as nitric oxide) but generally not very } \\
\text { reactive. }\end{array}$ \\
\hline Hydroxyl & $\mathrm{OH}^{\cdot}$ & $\begin{array}{l}\text { An oxygen centred radical. The most highly reactive } \\
\text { oxygen radical known. When generated in vivo, reacts } \\
\text { at its site of formation. }\end{array}$ \\
\hline Thiyl & RS & $\begin{array}{l}\text { General name for a group of radicals with an unpaired } \\
\text { electron residing on sulphur. Reactivity varies; often } \\
\text { react with oxygen to give damaging oxysulphur } \\
\text { radicals. }\end{array}$ \\
\hline Peroxyl, alkoxyl & $\mathrm{RO}_{2}{ }^{-}, \mathrm{RO}^{\bullet}$ & $\begin{array}{l}\text { Oxygen centred radicals formed during the breakdown of } \\
\text { organic peroxides. }\end{array}$ \\
\hline Oxides of nitrogen & $\mathrm{NO}{ }^{*}, \mathrm{NO}_{2}{ }^{\circ}$ & $\begin{array}{l}\text { Both are free radicals. NO }{ }^{*} \text { is formed in vivo from the } \\
\text { amino acid } \mathrm{L} \text {-arginine. } \mathrm{NO}_{2}^{\circ} \text { is made when } \mathrm{NO}^{*} \text { reacts } \\
\text { with oxygen, and is found in polluted air and smoke } \\
\text { from burning organic materials, such as cigarette } \\
\text { smoke. }\end{array}$ \\
\hline
\end{tabular}

^A superscript dot is used to denote free radical species.
Transition metals and hydrogen peroxide Many transition metals have variable oxidation numbers: for example iron as $\mathrm{Fe}^{2+}$ or $\mathrm{Fe}^{3+}$, and copper as $\mathrm{Cu}^{+}$or $\mathrm{Cu}^{2+}$. Changing between these oxidation states transfers single electrons, for example:

$$
\mathrm{Fe}^{3+}+\mathrm{e}^{-} \rightleftarrows \mathrm{Fe}^{2+}
$$

Also, for titanium salts:

$$
\mathrm{Ti}^{4+}+\mathrm{e}^{-} \rightleftarrows \mathrm{Ti}^{3+}
$$

Thus transition metal ions are good promoters of free radical reactions. For example, copper, iron and titanium ions react with $\mathrm{H}_{2} \mathrm{O}_{2}$ to form $\mathrm{OH}^{\cdot}$ radicals: ${ }^{4}$

$$
\begin{aligned}
& \mathrm{Cu}^{+}+\mathrm{H}_{2} \mathrm{O}_{2} \rightarrow \mathrm{Cu}^{2+}+\mathrm{OH}^{\bullet}+\mathrm{OH}^{-} \\
& \mathrm{Ti}^{3+}+\mathrm{H}_{2} \mathrm{O}_{2} \rightarrow \mathrm{Ti}^{4+}+\mathrm{OH}^{\bullet}+\mathrm{OH}^{-}
\end{aligned}
$$

$\mathrm{H}_{2} \mathrm{O}_{2}$ is produced in vivo by dismutation of $\mathrm{O}_{2}{ }^{--}$and by several oxidase enzymes, including xanthine oxidase. ${ }^{4}$ Like $\mathrm{O}_{2}{ }^{--}, \mathrm{H}_{2} \mathrm{O}_{2}$ can be useful in vivo; for example, it is a substrate for a thyroid peroxidase enzyme that helps make thyroid hormones. ${ }^{18}$ It can also regulate gene expression, for example by activating the cytoplasmic gene transcription factor NF-кB. ${ }^{19}$ $\mathrm{H}_{2} \mathrm{O}_{2}$ is very diffusible within and between cells, ${ }^{4}$ but if it comes into contact with transition metal ions, $\mathrm{OH}^{\bullet}$ will be generated at that site and cause immediate damage.

\section{hypertension. ${ }^{15}$}

mediated vasodilatation, for example in

The interaction of $\mathrm{O}_{2}{ }^{--}$and $\mathrm{NO}^{-}$can also be dangerous. ${ }^{5}$ The product, peroxynitrite (equation (2)) is not only directly toxic, for example by oxidising methionine and protein -SH groups, but also it breaks down to generate multiple toxic products (figure), including nitrogen dioxide gas $\left(\mathrm{NO}_{2}{ }^{\circ}\right), \mathrm{OH}^{\circ}$ and nitronium ion $\left(\mathrm{NO}_{2}{ }^{+}\right) .^{516}$ Some of these species will nitrate aromatic amino acids, so that formation of nitroaromatics (especially nitrotyrosine) is thought to be a 'marker' of peroxynitrite generation. ${ }^{5} 17$

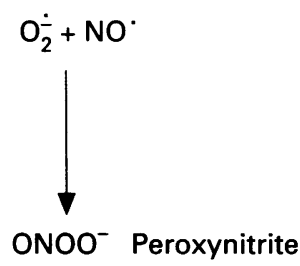

$\mathrm{H}^{+}$

$\mathrm{ONOOH}$ Peroxynitrous acid

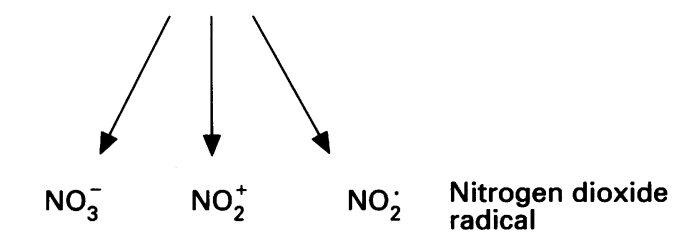

Nitrate ion Nitronium ion

$\mathrm{OH}^{-} \quad \mathrm{OH} \quad$ Hydroxyl radical

Formation and decomposition of peroxynitrite.

\section{Antioxidant defences}

ENZYMES

Living organisms have evolved multiple antioxidant defence systems. Superoxide dismutase (SOD) enzymes remove $\mathrm{O}_{2}{ }^{\circ-}$ by accelerating its dismutation by about four orders of magnitude. Human cells have an SOD enzyme containing active site manganese (MnSOD) in mitochondria, whereas cytosol contains a copper and zinc containing SOD (CuZnSOD). ${ }^{4} \mathrm{H}_{2} \mathrm{O}_{2}$ can be destroyed by catalases, but the most important $\mathrm{H}_{2} \mathrm{O}_{2}$ removing enzymes in human cells are glutathione peroxidases, which remove $\mathrm{H}_{2} \mathrm{O}_{2}$ by using it to oxidise reduced glutathione (GSH) to oxidised glutathione (GSSG):

$$
2 \mathrm{GSH}+\mathrm{H}_{2} \mathrm{O}_{2} \rightarrow \mathrm{GSSG}+2 \mathrm{H}_{2} \mathrm{O}
$$

Another important antioxidant defence is that iron and copper ions are kept safely protein bound whenever possible, so that $\mathrm{OH}^{*}$ formation is largely prevented. This is particularly important in extracellular fluids, including synovial fluid, because their levels of antioxidant defence enzymes are low. ${ }^{7} 2021$

The value of this sequestration of metal ions is illustrated by an inspection of the severe pathology suffered by patients with metal overload diseases. For example, in patients with iron overload secondary to idiopathic haemochromatosis, transferrin is iron saturated and iron ions 'catalytic' for free radical reactions circulate in the blood. ${ }^{22}$ Among many other problems, these patients can suffer joint
METAL ION SEQUESTRATION 
inflammation, ${ }^{23}$ illustrating the well known relationship between chronic inflammation and disordered iron metabolism. ${ }^{24}$

\section{$\alpha$-TOCOPHEROL}

This fat soluble vitamin functions as a chain breaking antioxidant in membranes and lipoproteins. ${ }^{25}$ When peroxyl radicals are generated during lipid peroxidation (table 1), they abstract hydrogen preferentially from the phenolic $-\mathrm{OH}$ group of tocopherol:

$$
-\mathrm{CO}_{2} \cdot+\mathrm{TOH} \rightarrow-\mathrm{CO}_{2} \mathrm{H}+\mathrm{TO}^{\bullet}
$$

This stops peroxyl radicals from attacking an adjacent fatty acid side chain or protein and terminates the chain reaction, hence the name chain breaking antioxidant. The $\alpha$-tocopherol radical, tocopherol- $\mathrm{O}^{*}$, is poorly reactive and is widely believed to migrate to the surface of membranes or lipoproteins for conversion back to $\alpha$-tocopherol by reaction with ascorbic acid.

\section{REPAIR SYSTEMS}

The antioxidant defences of the human body are not $100 \%$ efficient, so that some free radical damage occurs in the human body and repair systems are needed. Thus cells have enzymes that can repair oxidised DNA, degrade free radical damaged proteins, and remove lipid hydroperoxides from membranes. ${ }^{4}$

\section{Oxidative stress}

Oxidative stress is said to result when reactive oxygen species are generated in excess in the human body. ${ }^{26}$ This can occur if antioxidant concentrations are too low (severe malnutrition, for example, can deplete levels of $\alpha$-tocopherol and vitamin C) or if free radical formation is increased-for example by the action of certain toxins. ${ }^{4}$

Cells can tolerate mild oxidative stress, and often respond to it by increased synthesis of antioxidant defence enzymes and other protective proteins. However, severe oxidative stress can cause cell injury or even death; oxidative damage to DNA, proteins and lipids can damage or destroy cells. Cell death induced by oxidative stress can occur by necrosis or apoptosis. ${ }^{27}$ Oxidative stress causes increased intracellular free $\mathrm{Ca}^{2+28}$ and may release intracellular iron to catalyse $\mathrm{OH}^{\cdot}$ generation. ${ }^{29}$

\section{Reactive oxygen species in RA}

GENERAL PRINCIPLES

What is the role played by reactive oxygen species in human disease? Some diseases may be caused by oxidative stress, for example the sequelae of overexposure to ionising radiation ${ }^{4}$ and the neurodegeneration produced by chronic $\alpha$-tocopherol deficiency. ${ }^{30}$

For most human diseases, however, the oxidative stress is secondary to the primary disease process. ${ }^{29}$ For example, tissue injury recruits and activates neutrophils, which produce $\mathrm{O}_{2}{ }^{\cdot-}, \mathrm{H}_{2} \mathrm{O}_{2}, \mathrm{HOCl}$, and possibly $\mathrm{NO}{ }^{\bullet}$; in excess, these cause damage. Tissue injury releases iron and copper ions and haem proteins (haemoglobin and myoglobin), both catalytic for free radical reactions, from their normal intracellular storage sites; ${ }^{42}$ it also disrupts electron transport chains in mitochondria and endoplasmic reticulum, so that more electrons leak to oxygen to form $\mathrm{O}_{2}{ }^{\cdot-} \cdot{ }^{31}$ For such secondary oxidative stress, the key question is 'does it contribute significantly to disease pathology?'

\section{THE CASE OF RA}

Following the work of McCord, ${ }^{1}$ I showed that hyaluronic acid depolymerisation by $\mathrm{O}_{2}{ }^{\cdot-}$ generating systems in vitro is caused by iron dependent formation of $\mathrm{OH}^{\cdot}$ from $\mathrm{O}_{2}{ }^{\cdot-}$ and $\mathrm{H}_{2} \mathrm{O}_{2}$. ${ }^{32}$ The hydroxyl radical causes random fragmentation of hyaluronate, eventually producing oligosaccharides. ${ }^{33}$ How could $\mathrm{OH}^{\cdot}$ arise in the RA joint? 'Catalytic' copper ions were not detected in fresh synovial fluid, ${ }^{34}$ but 'catalytic' iron can be measured by the bleomycin assay in about $40 \%$ of synovial fluids aspirated from inflamed RA knee joints, ${ }^{35}$ and this iron has been directly demonstrated to stimulate lipid peroxidation. ${ }^{36}$ In addition, aspiration of synovial fluid from some RA patients into a solution of phenylalanine produces a pattern of hydroxylation products characteristic of $\mathrm{OH}^{\bullet}$ attack upon the aromatic ring ${ }^{37}$ suggesting that constituents of RA synovial fluid can lead to $\mathrm{OH}^{\bullet}$ formation.

The catalytic iron could arise by release from dead cells, by $\mathrm{H}_{2} \mathrm{O}_{2}$ mediated degradation of haemoglobin ${ }^{38}$ (released by traumatic microbleeding in the joint), or by the action of $\mathrm{O}_{2}{ }^{--}$ on synovial fluid ferritin. ${ }^{39}$ Release of iron upon exposure of synovial fluid to $\mathrm{O}_{2}{ }^{-}$, especially at acidic $\mathrm{pH}$, has been demonstrated. ${ }^{40}$ The chemical pattern of damage to hyaluronate in RA synovial fluids (as demonstrated using nuclear magnetic resonance ${ }^{33}$ ) is consistent with $\mathrm{OH}^{\cdot}$ attack, though hyaluronate may additionally be secreted as abnormally short chains in RA. ${ }^{41}$

Reaction of $\mathrm{O}_{2}^{--}$with $\mathrm{NO}^{-}$is another potential source of $\mathrm{OH}^{\circ}$, as the synthesis not only of $\mathrm{O}_{2}{ }^{--}$but also of $\mathrm{NO}^{-42}$ appears to be increased in RA patients. Demonstration of the presence of nitrotyrosines in patients with active $R^{4}{ }^{43}$ is consistent with formation of peroxynitrite (equation (1)) in vivo. ${ }^{5}$

A third source of $\mathrm{OH}^{\circ}$ is reaction of $\mathrm{O}_{2}{ }^{--}$ with $\mathrm{HOCl}^{44}$ both produced by activated phagocytes:

$$
\mathrm{O}_{2}^{\cdot-}+\mathrm{HOCl} \rightarrow \mathrm{O}_{2}+\mathrm{OH}^{\bullet}+\mathrm{Cl}^{-}
$$

SOURCES OF OXYGEN DERIVED SPECIES IN RA The most discussed source is activated phagocytes. Activated neutrophils liberate $\mathrm{O}_{2}{ }^{-}, \mathrm{H}_{2} \mathrm{O}_{2}$, elastase, $\mathrm{HOCl}$, and eicosanoids, and synovial fluid IgG aggregates may activate neutrophils. ${ }^{45}$ Hypochlorous acid and $\mathrm{O}_{2}{ }^{\circ-}$ both react with ascorbate, which may help to explain the low levels of ascorbate in RA body fluids. $^{74}$ Hypochlorous acid inactivates 
$\alpha_{1}$-antiproteinase, an important inhibitor of serpins (such as elastase), and the amount of active $\alpha_{1}$-antiproteinase is decreased in $R A ;{ }^{47}$ $\mathrm{HOCl}$ also fragments collagen. ${ }^{48}$ The pannus contains many macrophage-like cells, presumably secreting $\mathrm{O}_{2}{ }^{--}, \mathrm{H}_{2} \mathrm{O}_{2}{ }^{49}$ and, possibly, $\mathrm{NO}^{-}$(it is not yet clear if neutrophils or macrophages in the RA joint make NO').

It has also been proposed that the inflamed rheumatoid joint, upon movement and rest, undergoes a hypoxia-reperfusion cycle, which may result in free radical generation by several mechanisms. ${ }^{50}$ It is interesting to note that one of these mechanisms is xanthine oxidase, ${ }^{51} 52$ relating back nicely to the original work of McCord. ${ }^{1}$

DRUG-DERIVED RADICALS

A few anti-inflammatory drugs may scavenge reactive oxygen species in vivo, but this ability is not widespread. ${ }^{53}$ Indeed, the reverse can be true: several drugs used in the treatment of $\mathrm{RA}$ might themselves be converted into free radicals in vivo. Thus they could suppress the signs of RA whilst aggravating oxidative damage. For example, radicals derived from penicillamine, phenylbutazone, some fenamic acids, and the aminosalicylate component of sulphasalazine, might inactivate $\alpha_{1}$-antiproteinase, deplete ascorbic acid and accelerate lipid peroxidation. ${ }^{53-55}$

\section{Consequences of oxidative stress in RA}

There is no doubt that oxidative stress occurs in RA patients (table 2)..$^{56-71}$ Lunec et al ${ }^{67}$ have argued that oxidative damage to IgG generates protein aggregates that can activate neutrophils and set up a 'vicious cycle' of free radical production.

Does oxidative stress contribute to cartilage and bone destruction in RA? The answer is

Table 2 Evidence consistent with oxidative stress in rheumatoid disease

\begin{tabular}{|c|c|c|}
\hline Observation & Reference & Comment \\
\hline $\begin{array}{l}\text { Increased lipid peroxidation } \\
\text { products in serum and } \\
\text { synovial fluid }\end{array}$ & 56 & $\begin{array}{l}\text { Decreased } \alpha \text {-tocopherol (per unit lipid) in } \\
\text { synovial fluid }{ }^{57} \text { is consistent with increased } \\
\text { lipid peroxidation, as are reports of foam cells' } \\
\text { containing oxidised low density lipoprotein in } \\
\text { rheumatoid synovium }{ }^{58} \text { and increased levels of } \\
\text { 4-hydroxy-2-nonenal, a cytotoxic product } \\
\text { generated by the decomposition of lipid } \\
\text { peroxides, in RA. }\end{array}$ \\
\hline $\begin{array}{l}\text { Depletion of ascorbate in } \\
\text { serum and synovial fluid }\end{array}$ & See text & $\begin{array}{l}\text { Presumably results from oxidation of ascorbate } \\
\text { during its antioxidant action. Activated } \\
\text { neutrophils also take up oxidised ascorbate } \\
\text { rapidly. }{ }^{60}\end{array}$ \\
\hline $\begin{array}{l}\text { Increased exhalation of } \\
\text { pentane }\end{array}$ & 61 & $\begin{array}{l}\text { A putative endproduct of lipid peroxidation, }{ }^{4} \\
\text { although its validity as an assay is debated. }{ }^{62}\end{array}$ \\
\hline $\begin{array}{l}\text { Increased concentrations of } \\
\text { uric acid oxidation } \\
\text { products }\end{array}$ & 63 & $\begin{array}{l}\text { Products measured appear to be endproducts of } \\
\text { free radical attack upon uric acid. }{ }^{6}{ }_{64}\end{array}$ \\
\hline $\begin{array}{l}\text { Formation of } 2,3 \text {-dihydroxy- } \\
\text { benzoate }(2,3-\mathrm{DHB}) \text { from } \\
\text { salicylate in increased } \\
\text { amounts }\end{array}$ & 65 & $\begin{array}{l}\text { 2,3-DHB appears to be a product of attack of } \\
\text { OH· upon salicylate in patients taking } \\
\text { aspirin. }\end{array}$ \\
\hline $\begin{array}{l}\text { Degradation of hyaluronic } \\
\text { acid by free radical } \\
\text { mechanisms }\end{array}$ & - & See text. \\
\hline $\begin{array}{l}\text { Formation of 'fluorescent' } \\
\text { proteins }\end{array}$ & 67,68 & $\begin{array}{l}\text { Fluorescence probably caused by oxidative } \\
\text { damage to amino acid residues in proteins. }\end{array}$ \\
\hline $\begin{array}{l}\text { Increased steady state levels } \\
\text { (in cellular DNA) and } \\
\text { increased urinary excretion } \\
\text { of 8-hydroxy-deoxyguano- } \\
\text { sine (80HdG) }\end{array}$ & 69,70 & $\begin{array}{l}\text { 80HdG is a major product of oxidative damage } \\
\text { to DNA. }\end{array}$ \\
\hline $\begin{array}{l}\text { Increased levels of 'protein } \\
\text { carbonyls' in synovial fluid }\end{array}$ & 71 & $\begin{array}{l}\text { Protein carbonyls are an endproduct of oxidative } \\
\text { damage to proteins. }\end{array}$ \\
\hline
\end{tabular}

unclear. Hydroxyl radicals degrade isolated proteoglycans $s^{132} 33$ and $\mathrm{HOCl}$ fragments collagen, ${ }^{48}$ but their effects on intact cartilage are probably limited. However, $\mathrm{H}_{2} \mathrm{O}_{2}$ is very diffusible and inhibits cartilage proteoglycan synthesis, ${ }^{72}$ for example by interfering with ATP synthesis. ${ }^{73}$ Indeed, intra-articular injection of $\mathrm{H}_{2} \mathrm{O}_{2}$ generating systems causes severe joint damage in animals. ${ }^{74}$ Hence inhibition of cartilage repair systems could aggravate the effects of proteolytic and free radical mediated cartilage degradation. $\mathrm{HOCl}$ can also activate latent forms of neutrophil collagenases and gelatinase, though the extent to which this happens in vivo is uncertain. ${ }^{75}$ Chondrocytes are damaged by $\mathrm{H}_{2} \mathrm{O}_{2}{ }^{76}$ and it has been suggested that low concentrations of $\mathrm{H}_{2} \mathrm{O}_{2}, \mathrm{O}_{2}{ }^{-}$, or both, accelerate bone resorption by osteoclasts, ${ }^{77} 78$ whereas NO inhibits it. ${ }^{79}$ In addition, ascorbate is essential for cartilage function ${ }^{80}$ and the low concentrations found in RA synovial fluid might impair cartilage metabolism. The current interest in the role of tumour necrosis factor $\alpha$ $(\mathrm{TNF} \alpha)$ in $\mathrm{RA}^{81}$ may relate to observations that $T N F \alpha$ causes oxidative stress. ${ }^{82} 83$

In summary, we do not as yet know the exact contribution made by reactive oxygen species to joint damage in RA. The development of improved assays of oxidative damage that are applicable to humans ${ }^{29}$ should help to address this point and allow a rational selection of antioxidants for possible therapeutic application. ${ }^{84}$

I thank the Arthritis and Rheumatism Council for research support.

1 McCord J M. Free radicals and inflammation. Science 1974; 185: 529-31.

2 Greenwald $R$ A. Oxygen radicals, inflammation, and arthritis. Semin Arthritis Rheum 1991; 20: 219-40.

3 Dowling E J, Chander C L Claxson A W, Lillie C, Blake D R. Assessment of a human recombinant manganese superoxide dismutase in models of inflammation. Free Radic Res Commun 1993; 18: 291-8.

4 Halliwell B, Gutteridge J M C. Free radicals in biology and medicine. Oxford: Clarendon Press, 1989.

5 Beckman J S, Chen J, Ischiropoulos H, Crow J P. Oxidative chemistry of peroxynitrite. Methods Enzymol 1994; 233: 229-40.

6 Curnutte J T, Babior B M. Chronic granulomatous disease. Adv Hum Genet 1987; 16: 229-45.

7 Blake D R, Hall N D, Treby D A, Halliwell B, Gutteridge J M C. Protection against superoxide and hydrogen peroxide in synovial fluid from rheumatoid hydrogen peroxide in synovial

8 Palmer R M J, Hickery M S, Charles I G, Moncada S, Bayliss M T. Induction of nitric oxide synthase in human chondrocytes. Biochem Biophys Res Commun 1993; 193: 398-405.

9 Carreras M C, Pargament G A, Catz S D, Poderoso J J, Boveris $A$. Kinetics of nitric oxide and hydrogen peroxide production and formation of peroxynitrite during the respiratory burst of human neutrophils. FEBS Lett 1994; 341: $65-8$.

10 Rathakrishnan C, Tiku K, Raghavan A, Tiku M L. Release of oxygen radicals by articular chondrocytes. $\mathcal{F}$ Bone Miner Res 1992; 7: 1139-48.

11 Tiku M L, Liesch J B, Roberston F M. Production of hydrogen peroxide by rabbit articular chondrocytes. Immunol 1990; 145; $690-6$.

12 Key L L Jr, Ries W L, Glasscock H, Rodriguiz R, Jaffe H. Osteoclastic superoxide generation. Int $\mathcal{f}$ Tissue React 1992; XIV: 295-8.

13 Meier B, Radeke $\mathrm{H} \mathbf{H}$, Selle $\mathrm{S}$, et al. Human fibroblasts release reactive oxygen species in response to treatment release reactive oxygen species in response to treatment with synovial fluids from patients suffering

14 Weiss $S \mathrm{~J}$. Tissue destruction by neutrophils. $N$ Engl $f$ Med 1989 ; 320: 365-76.

15 Nakazono $\mathrm{K}$, Watanabe $\mathrm{N}$, Matsumo $\mathrm{K}$, et al. Does superoxide underly the pathogenesis of hypertension? Proc Natl Acad Sci USA 1991; 88: 10045-8. 
16 Van der Vliet A, O'Neill C A, Halliwell B, Cross C E, Kaur $\mathrm{H}$. Aromatic hydroxylation and nitration of phenylalanine and tyrosine by peroxynitrite. FEBS Lett 1994; 339: 89-92.

17 van der Vliet A, Smith D, O'Neill C A, et al. Interactions of peroxynitrite with human plasma and its constituents: oxidative damage and antioxidant depletion. Biochem $f$ 1994; 303: 295-301.

18 Dupuy C, Virion A, Ohayon R, et al. Mechanism of hydrogen peroxide formation catalyzed by NADPH oxidase in thyroid plasma membrane. $₹$ Biol Chem 1991; 266: $3739-43$.

19 Schreck R, Albermann K, Baeuerle P A. Nuclear factor kappa B: an oxidative stress-responsive transcription
factor of eukaryotic cells (a review). Free Radic Res factor of eukaryotic cells

20 Halliwell B, Gutteridge J M C. The antioxidants of human extracellular fluids. Arch Biochem Biophys 1990; 280: $1-8$.

21 Biemond P, Swaak A J G, Koster J F. Protective factors against oxygen free radicals and hydrogen peroxide in rheumatoid arthritis synovial fluid. Arthritis Rheum 1984, 27: 760-5.

22 Gutteridge J M C, Rowley D A, Griffiths E, Halliwell B. Low-molecular-weight iron complexes and oxygen radical reactions in idiopathic haemochromatosis. Clin Sci 1985; 68: $463-7$

23 McLaren G D, Muir W A, Kellermeyer R W. Iron overload disorders. CRC Crit Rev Clin Lab Sci 1983; 19: 205-66.

24 Means R T Jr, Krantz S B. Progress in understanding the pathogenesis of the anemia of chronic disease. Blood 1992; 80: 1639-47.

25 Burton G W, Traber M G. Vitamin E: antioxidant activity, biokinetics and bioavailability. Ann Rev Nutr 1990; 10: 357-82.

26 Sies H. Oxidative stress II. Oxidants and antioxidants. New York and London: Academic Press, 1989.

27 Sarafian T A, Bredesen D E. Is apoptosis mediated by reactive oxygen species? Free Radic Res 1994; 21: 1-8.

28 Orrenius S, McConkey D J, Bellomo G, Nicotera P. Role of $\mathrm{Ca}^{2+}$ in toxic cell killing. Trends Pharm Sci 1989; 10: $281-5$

29 Halliwell B, Gutteridge J M C, Cross C E. Free radicals, antioxidants and human disease: where are we now? $\mathcal{f} \mathrm{Lab}$ Clin Med 1992; 119: 598-620.

30 Muller D P R, Goss-Sampson M A. Neurochemical, neurophysiological and neuropathological studies in vitamin E deficiency. Crit Rev Neurobiol 1990; 5: 239-65.

31 Ambrosio G, Zweier J L, Duilio C, et al. Evidence that mitochondrial respiration is a source of potentially toxic oxygen free radicals in intact rabbit hearts subjected to ischemia and reflow. $\mathcal{F}$ Biol Chem 1993; 268: $18532-41$.

32 Halliwell B. Superoxide-induced generation of hydroxyl radicals in the presence of iron salts. Its role in degradation of hyaluronic acid by a superoxide-generating system. FEBS Lett 1978; 96: 238-42.

33 Grootveld $M$, Henderson E B, Farrell A, Blake D R, Parkes H G, Haycock P. Oxidative damage to hyaluronate and glucose in synovial fluid during exercise of the inflamed rheumatoid joint. Biochem f 1991; 273: 459-67.

34 Winyard P G, Pall H, Lunec J, Blake D R. Noncaeruloplasmin copper (phenanthroline-copper) is not present in fresh serum or synovial fluid from patients with present in fresh serum or synovial fluid from patient

35 Gutteridge J M C. Bleomycin-detectable iron in knee-joint synovial fluid from arthritic patients and its relationship
to the extracellular antioxidant activities of caeruloto the extracellular antioxidant activities of caerulo-
plasmin, transferrin and lactoferrin. Biochem $\mathcal{f} 1987 ; 245$ : plasmin

36 Gutteridge J M C, Rowley D A, Halliwell B. Superoxidedependent formation of hydroxyl radicals and lipid peroxidation in the presence of iron salts. Biochem $\mathcal{F} 1982$; 206: 605-9.

37 Kaur H, Fagerheim I, Grootveld M, Puppo A, Halliwell B. Aromatic hydroxylation of phenylalanine as an assay for hydroxyl radicals. Anal Biochem 1988; 172: 360-7.

38 Gutteridge J M C. Iron promoters of the Fenton reaction and lipid peroxidation can be released from haemoglobin and lipid peroxidation can be released from

39 Biemond P, Swaak A J G, Van Eijk H G, Koster J F. Intraarticular ferritin-bound iron in rheumatoid arthritis. Arthritis Rheum 1986; 29: 1187-93.

40 Kawasaki N, Tanimoto T, Tanaka A, Hayakawa T, Miyasaka N. Determination of non-protein-bound iron in human synovial fluid by high-performance liquid chromatography with electrochemical detection. f Chromatogr 1994; B656: 436-40.

41 Henderson E B, Grootveld M, Farrell A, Smith E C, Thompson $\mathrm{P}$ W, Blake D R. A pathological role for damaged hyaluronan in synovitis. Ann Rheum Dis 1991; 50: 196-200.

42 Farrell A J, Blake D R, Palmer R M J, Moncada S. Increased concentrations of nitrite in synovial fluid and serum samples suggest increased nitric oxide synthesis in rheumatic diseases. Ann Rheum Dis 1992; 51: 1219-22.

$43 \mathrm{Kaur} \mathrm{H}$, Halliwell B. Evidence for nitric oxide-mediated oxidative damage in chronic inflammation. FEBS Lett 1994; 350: 9-12

44 Candeias L P, Patel K B, Stratford M R L, Wardman P. Free hydroxyl radicals are formed on reaction between the neutrophil-derived species superoxide anion and hypochlorous acid. FEBS Lett 1993; 333: 151-3.
45 Robinson J, Watson $F$, Bucknall $R$ C, Edwards $S$ W. Activation of neutrophil reactive-oxidant production by synovial fluid from patients with inflammatory joint disease. Biochem f 1992; 286: 345-51.

46 Halliwell B, Wasil M, Grootveld M. Biologically-significant scavenging of the myeloperoxidase-derived oxidant hypochlorous acid by ascorbic acid. FEBS Lett 1987; 213: 15-8.

47 Chidwick K, Winyard P G, Zhang Z, Farrell A J, Blake D R. Inactivation of the elastase inhibitory capacity of $\alpha_{1}$-antitrypsin in fresh samples of synovial fluid from patients with rheumatoid arthritis. Ann Rheum Dis 1991; 50: $915-6$.

48 Davies J M S, Horwitz D A, Davies K J A. Potential roles of hypochlorous acid and $\mathrm{N}$-chloroamines in collagen breakdown by phagocytic cells in synovitis. Free Radic Biol Med 1993; 15: 637-43.

49 Hoffstein S T, Gennaro D E, Meunier P C. Cytochemical demonstration of constitutive $\mathrm{H}_{2} \mathrm{O}_{2}$ production by macrophages in synovial tissue from rats with adjuvant arthritis. Am f Pathol 1988; 130: 120-5.

50 Merry P, Grootveld M, Lunec J, Blake D R. Oxidative damage to lipids within the inflamed human joint provides evidence of radical-mediated hypoxicreperfusion injury. Am $\mathcal{f}$ Clin Nutr 1991; 56: 362-9S.

51 Stevens C R, Benboubetra $M$, Harrison R, Sahinoglu T, Smith E C, Blake D R. Localization of xanthine oxidase to synovial endothelium. Ann Rheum Dis 1991; 50:

52 Miesel R, Zuber M. Elevated levels of xanthine oxidase in serum of patients with inflammatory and autoimmune rheumatic diseases. Inflammation 1993; 17: 551-61.

53 Halliwell B, Evans P J, Kaur H, Chirico S. Drug-derived radicals: mediators of the side effects of anti-inflammatory drugs? Ann Rheum Dis 1992; 51: 1261-3.

54 Grisham M B, Ware K, Marshall S, Yamada T, Sandhu I S. Pro-oxidant properties of 5-aminosalicylic acid. Dig Dis Sci 1992; 37: 1383-9.

55 Evans P J, Akanmu D, Halliwell B. Promotion of oxidative damage to arachidonic acid and $\alpha_{1}$-antiproteinase by antiinflammatory drugs in the presence of the haem proteins myoglobin and cytochrome c. Biochem Pharmacol 1994; 48: 2173-9.

56 Rowley D A, Gutteridge J M C, Blake D R, Farr M, Halliwell B. Lipid peroxidation in rheumatoid arthritis. Clin Sci 1984; 66: 691-5.

57 Fairburn K, Grootveld M, Ward R J, et al. $\alpha$-Tocopherol, lipids and lipoproteins in knee-joint synovial fluid and serum from patients with inflammatory joint disease. Clin Sci 1992; 83: 657-64.

58 Winyard $P$ G, Tatzber $F$, Esterbauer $H$, Kus $M$ L, Blake D R, Morris C J. Presence of foam cells containing oxidized low density lipoprotein in the synovial memoxidized low density lipoprotein in the synovial memDis 1993; 52: 677-80.

59 Selley M L, Bourne D J, Bartlett M R, et al. Occurrence of (E)-4-hydroxy-2-nonenal in plasma and synovial fluid of patients with rheumatoid arthritis and osteoarthritis. Ann Rheum Dis 1992; 51: 481-4.

60 Washko P, Rotrosen D, Levine M. Ascorbic acid transport and accumulation in human neutrophils. $7 \mathrm{Biol}$ Chem 1989; 264: 18996-9002.

61 Humad S, Zarling E, Clapper M, Skosey J K. Breath pentane excretion as marker of disease activity in rheumatoid arthritis. Free Radic Res Commun 1988; 5: $101-6$.

62 Phillips M, Greenburg J, Sabas M. Alveolar gradient of pentane in normal human breath. Free Radic Res 1994; 20: 333-7.

63 Grootveld M, Halliwell B. Measurement of allantoin and uric acid in human body fluids. Biochem $\mathcal{f}$ 1987; 243: 803-8.

64 Kaur H, Halliwell B. Action of biologically-relevant oxidizing species upon uric acid. Chem Biol Interact 1990; 73: $235-47$.

65 Grootveld M, Halliwell B. Aromatic hydroxylation as a potential measure of hydroxyl radical formation in vivo. Biochem f 1986; 237: 499-504

66 Ingelman-Sundberg $\mathrm{M}$, Kaur $\mathrm{H}$, Terelius $\mathrm{Y}$, Persson J O, Halliwell $\mathrm{B}$. Hydroxylation of salicylate by microsomal fractions and cytochrome P-450. Biochem f 1991; 276: 753-7.

67 Lunec J, Blake D R, McCleary S J, Brailsford S, Bacon P A. Self-perpetuating mechanisms of immunoglobulin $\mathrm{G}$ aggregation in rheumatoid inflammation. f Clin Invest 1985; 76: 2084-90.

68 Jasin H E. Oxidative cross-linking of immune complexes by human polymorphonuclear leukocytes. $\mathcal{F}$ Clin Invest 1988; 81: $6-15$.

69 Bashir S, Harris G, Denman M A, Blake D R, Winyard P G. Oxidative DNA damage and cellular sensitivity to oxidative stress in human autoimmune disease. Ann Rheum Dis 1993; 52: 659-66.

70 Lunec J, Herbert K, Blount S, Griffiths H R, Emery P. 8-Hydroxydeoxyguanosine. A marker of oxidative DNA damage in systemic lupus erythematosus. FEBS Lett damage in syste

71 Chapman M L, Rubin B R, Gracy R W. Increased carbonyl content of proteins in synovial fluid from patients with rheumatoid arthritis. $\mathcal{F}$ Rheumatol 1989; 16: 15-18.

72 Bates E J, Johnson C C, Lowther D A. Inhibition of proteoglycan synthesis by hydrogen peroxide in cultured bovine articular cartilage. Biochim Biophys Acta 1985; 838: $221-8$. 
73 Baker M S, Bolis S, Lowther D A. Oxidation of articular cartilage glyceraldehyde-3-phosphate dehydrogenase (G3PDH) occurs in vivo during carrageenin-induced arthritis. Agents Actions 1991; 32: 299-304

74 Schalkwijk J, Van den Berg W B, Van de Putte L B A, Joosten L B A. An experimental model for hydrogen peroxide-induced tissue damage. Arthritis Rheum 1986; 29: 532-8

75 Michaelis J, Vissers M C, Winterbourn C C. Different effects of hypochlorous acid on human neutrophil metalloproteinases. Arch Biochem Biophys 1992; 292: 555-62.

76 Vincent F, Corral M, Defer N, Adolphe M. Effect of oxygen free radicals on articular chondrocytes in culture. Exp Cell free radicals on articular

77 Garrett I R, Boyce B F, Oreffo R O C, Bonewald L, Poser J, Mundy G R. Oxygen-derived free radicals stimulate osteoclastic bone resorption in rodent bone in vitro and in vivo. $\mathcal{F}$ Clin Invest 1990; 85: 632-39.

$78 \mathrm{Bax}$ B E, Alam A S M T, Banerji B, et al. Stimulation of osteoclastic bone resorption by hydrogen peroxide. Biochem Biophys Res Commun 1992; 183: 1153-8.
79 MacIntyre I, Zaidi M, Alam A S M, et al. Osteoclastic inhibition: An action of nitric oxide not mediated by cyclic GMP. Proc Natl Acad Sci USA 1991; 88: 2936-40.

80 Shapiro I M, Leboy P S, Tokuoka T, et al. Ascorbic acid regulates multiple metabolic activities of cartilage cells. Am f Clin Nutr 1991; 54: 1209-13S

81 Williams R O, Feldmann M, Maini R N. Anti-tumor necrosis factor ameliorates joint disease in murine collagen-induced arthritis. Proc Natl Acad Sci USA 1992; 89: 9784-8.

82 Zimmerman R J, Chan A, Leadon S C. Oxidative damage in murine tumor cells treated in vitro by recombinant human tumor necrosis factor. Cancer Res 1989; 49: 1644-8.

83 Schulze-Osthoff K, Bakker A C, Vanhaesebroeck B, et al. Cytotoxic activity of tumor necrosis factor is mediated by early damage of mitochondrial functions. Evidence for the involvement of mitochondrial radical generation. $\mathcal{f} \mathrm{Biol}$ Chem 1992; 267: 5317-23.

84 Halliwell B. Drug antioxidant effects. A basis for drug selection? Drugs 1991; 42: 569-605. 